\title{
Epidemiology of Listerosis in Animal and Human in Ethiopia
}

Received: 16 September, 2020 Accepted: 11 November, 2020 Published: 18 November, 2020

*Corresponding author: Sagni Diba Bayata, Department of Animal Science, Bishoftu, Ethiopia, E-mail: segni.diba2007@gmail.com

Keywords: Animals; Epidemiology; Ethiopia; Human; Listeria

https://www.peertechz.com

Check for updates

Check for updates

Department of Animal Science, Bishoftu, Ethiopia

\section{Abstract}

Listeriosis is an important food borne bacterial disease for both human and animals. The objective of the paper was to review the Epidemiology of listeria in animal and human in Ethiopia. From the studies conducted in different area of the country 7 species of Listeria were reported namely: L. monocytogenes, L. innocua, L. welshimeri, L. seeligeri, and L. ivanovii, and L. grayi, L. welshimeri. Among those species L. monocytogenes is the most species that is zonootic for both humans and animals. Occasionally L. seeligeri, L. ivanovii are affected animals and humans. The overall prevalence of the listeriosis was reported in the country: $3.8 \%, 14 \%, 20 \%, 20.8 \%, 24.2 \%$, $25,26.1,26.6 \%, 27.5 \%, 28.4 \%, 32.6 \%, 32.9 \%$ and $42.9 \%$ respectively. The most common source of infection: human feces, animal feces, aborted fetus, soil, both farm and surface water troughs, animals feed and the walls. The main Reservoir, risk factors for distribution of the disease are forage, water, mud, silage and host, management, pathogenic risk factors respectively. Pregnant women and their fetuses, newborn babies, the elderly and immunocompromised individuals are the people at risk for the disease. The major clinical forms of listeria in cattle are encephalitis, abortion, endocarditics, conjunctivitis, metrits and meningitis. The ways to control of disease in foods relies largely on Hazard analysis critical point approach and the establishment of effective critical control points in food industry. The preparation of silage should be made for good quality, with early cutting of grass, reduce contamination with soil and ensuring optimal anaerobic fermentation, which will insure that the pH falls below 5 levels for inhibited growth of Listeria species. They must be improving hygienic management for animals and health educations for peoples about the disease for reduce infection.

\section{Introduction}

Listeriosis is the most important emerging food borne of bacterial zoonotic infections in worldwide that arises mainly from the consumption of contaminated food [1]. It is recognized in 1920 for the first time as an infectious disease of rodents and pigs [2]. In developing countries there have been few information on listeriosis, because there is no given attentions and laboratory facilities awareness on the occurrence of listeria species in food [3].

In Ethiopia the disease was occurs, due to ingestion of unpreserved silage and contamination of feed in animal [4]. In veterinary the bacteria can be transmitted though ingestion of

Contamination feed and discharges from the infected cow, the disease can infect both animal and human [5]. Contaminated of vegetables and ready-to-eat meat have been implicated in over as disease for public healthy $[6,7]$. The Epidemiology of disease was varies as country authors are reported their Studies in different area from the investigation of the disease with different prevalence i.e. the highest prevalence were reported $42.9 \%$ from contamination of vegetables [8] and the Lowest prevalence were reported $3.8 \%$ from meat and meat product [9].

The older, adults, pregnant women, newborns with immunocompromised systems are highly susceptible of the diseases in both animals and humans. The source of infection of the disease are contaminated milk, cheese, meat are consumed and caused L. monocytogenes in human. Contamination of animals feed like silage and human food from animal products considered as a risk factor of listeriosis outbreaks in Ethiopia [10]. The symptoms observed in the affected animals and human included meningitis, still birth, fever, watery diarrhea, nausea, headache, and pain in joints and muscles. Occasionally symptoms like fever, bloody diarrhea and bacteremia are observed [11].

The responsibilities towards to diagnosis of the disease could be by using Conventional cultural method such isolation of agents, Fluorescent Antibody Techniques (FA), inoculation, serological technique, and Polymerase Chain Reaction (PCR) are used to identify Listeria species in laboratory [12]. The optimal treatment of the disease is antibiotics combination such as Trimethoprim and Tetracycline [13]. The best control 
measured of the disease was using Hazard Control Critical Points (HACCP) principles and the establishment of effective critical control points in the process [14].

The economic importance of disease due to production loss abortion, treatment cost, reduces welfare and trade of animal and their by product [15]. The Public healthy importance of the disease pathogen due to contaminated foods of animal origin and disease associated with the expanding immune suppressed, elder, pregnant human population [16].

Therefore the objective of the paper was:

$\checkmark$ To Review the Epidemiology of Listeria in animals and humans in Ethiopia

\section{Literature review}

Overview of listeria: Listeria is found widely in nature. It is primarily food borne bacterial disease in domestic animals and humans. Species of Listeria have been isolated from at least 37 species of mammals and 17 species of birds, and from others like flies, ticks, fish, and crustaceans. Several subtypes can be distinguished by laboratory tests. The bacteria were available more common in temperate zones than in tropics. Outbreaks of food-borne listeriosis have been reported from Canada, Switzerland and USA with high fatality rates [17]. In Ethiopia the disease has been reported 2004 in meat, cheese, fish, and pork poultry [10]. The bacterium is often isolated in cattle, sheep, and fowl, and is also found in dairy products, fruits, and vegetables [18].

\section{Etiological and morphological characteristics}

Listeria is pleomorphic gram positive, facultative anaerobic, motile, no spore-forming, the intracellular rod shaped bacterium. The taxonomic characteristic order of bacillales, family, listeriaceae, size 0.4-0.5micrometer up to 0.5-2 micro meter, nucleic acid, grows as saprobe in soil, silage, animal manure, sewage, litter, bird dropping, Listeria species are psychrophilic the growth at cold temperature $\left(0^{\circ} \mathrm{C}\right)$. Contain 13 sero-groups of which 1 and 4 are most common. $L$. monocytogenes is main cause of disease in animals and humans; also L. ivanovii and L. seeligeri occasionally cause disease in humans [18].

\section{Clinical Sign}

In animals: the common symptoms observed Meningoencephalitic form Involves neurological signs, dullness, drooling, lack of interest in food, lateral deviation of the head with a tendency to circle, marked salivation, paralysis then recumbence. Visceral form including: Abortion with retained placenta, still birth, micro abscesses occur throughout the brain, and heart [19].

Human symptoms two observed as febrile gastroenteritis form and invasive systemic disease form. In case of febrile gastroenteritis from the Incubation period of the disease type ranges from 9-48 $\mathrm{h}$ after ingestion of contaminated item. The individuals developed, Watery diarrhea, fever, chills, nausea, and vomiting are the main presenting feature. The
Invasive systemic disease form of disease is associated with immunologically challenged populations. The groups include pregnant women, unborn fetuses, infants, and elderly people with reduced immunity due to diseases and People taking special medications, such as steroids and chemotherapeutic agents to treat cancer. It crosses blood brain barrier causing inflammation of meningitis and brain stem. In pregnant women, it can pass through the placental barrier infecting the fetus. Abortion and stillbirth follows. Fever, myalgias, CNS signs are the main presenting feature [20].

\section{Diagnosis and treatment}

Diagnostic approach of Listeria depends on clinical sign, epidemiological information and history. In all cases sample should be collected from the patient and laboratory testing should be requested. Specimens for cases of abortion should include cotyledons, fetal abomasal contents and uterine discharges. Suitable samples from septicemic cases include liver, spleen and blood [7]. For isolation and identification of species be inoculated directly onto blood agar, selective blood agar containing $0.05 \%$ potassium tellurite. The plates are incubated aerobically at $37^{\circ} \mathrm{C}$ for 24 to 48 hours. Commercially indicator media are available such Listeria Oxoford which is selective agar and these are designed mainly for the isolation of Listeria from human food stuffs [21]. The other most important methods for identification test of listeria species in laboratory is Molecular Methods [22].

The optimal antibiotic treatment fot listeriosis was penicillin, ampicillin, erythromycin rifampicin, chloramphenicol, tetracycline and aminoglycosides, with the exception of cephalosporin are effective against $L$. monocytogenes. A combination of trimethoprim and tetracycline was more effectives [23].

\section{Controls and prevention}

The best controls strategies of listeria in human should be creating awareness among the consumers, farmers and those raising farm animals and using their products. The improvement of farming conditions and relies on HACCP principles [24].

In animals provision of good quality silage and reduce of stressful conditions like dense stocking rates and minimizing ingestion of soil-contaminated pastures [25]. In epidemic area early detection of a listeriosis outbreak and efficient intervention are important in preventing methods. Typing of food isolates and comparison with clinical isolates may also lead authorities to contaminated food processing plants [26]. A pasteurization technique eliminates Listeria species from most dairy associated outbreaks. Providers should be maintaining enough suspicion for Listeria infection to draw blood cultures for any woman at risk [27].

\section{Epidemiology of listeriosis in Ethiopia}

Occurrences: In Ethiopia like other Africa countries most of few reports on listeriosis due to no well-organized epidemiological surveillance systems and few studies in limited 
areas absence awareness of its occurrence of the disease at national level [28]. However nowadays there are some reports on different samples from different part of the country are summarized in the Table 1.

\section{Source of infection and mode of transmission}

The major source of infection was animal feces, human feces, farm surry, sewerage sludge, farm water troughs, surface water, and plants animal feed and the walls. The zoonotic one L. monocytogenes formulated feeds but, its multiplication is restricted [29].

The organisms available in the feed of animal, silage but not multiply to any significant extent in effectively preserved silage which is characterized by anaerobic storage, high density, a high concentration of organic acids and a pH below 4.5. It may be present in silage which is poorly fermented when silage contains soil its risk to contaminate by Listeria. Infected animals can also serve as a source of infection from their urine, feces, aborted fetuses, uterine discharges and the milk [7].

The most common route of infection inadequately pasteurized milk, soft cheeses, and ice Cream and other dairy products also are important sources pregnant women can transmit the infection to their unborn fetuses. Calves may acquire infection from contamination of cow teat, ingestion of milk containing the organism from carrier's animals. The encephalitic form of the disease results from infection of the terminals of the trigeminal nerve consequent to abrasion of the buccal mucosa from feed. Myelitis is result from growth up to spinal nerves subsequent to body area infections [30].

\section{Reservoirs}

Listeria species are widely dispersed in the natural environment, including soil, water and decaying vegetation. Common animal reservoirs include domestic and wild mammals such as cattle, sheep and fowls. Humans may also act as reservoirs, particularly abattoir workers and laboratory workers exposed to L. monocytogenes culture [31].

\section{Risk factors}

Host risk factors: The organisms was Regarding sensitivity, virtually in both wild and domestic animals are susceptible to infection. In cattle it develops sporadically, having a stationary character, without tendency to disseminate in the outbreak. Morbidity and mortality varies according to clinical form [31].

Management risk factor: The most common risk factors for Listeria species is that reduce host immune response includes poor nutritional status, transport, overcrowding and insanitary conditions with poor access to feed supplies [32].

Pathogenic risk factor: The other risk factors of the organism are pathogenic of infection increases due to a massive multiplication of Listeria species in the feed or environment. The most important aspect in food hygiene is the ability of the bacteria to survive in a wide range of temperatures and to make biofilms on solid surfaces, including food processing facilities, which are more resistant to disinfectants and sanitizing agents [13]

\section{Population at risk}

Ages: The major age at risk are newborn babies and the elderly with age starting greater than 65 Year. Their Immune systems of those elders are very immature and also older age immune systems very weak for response to infection and extremely susceptible to these types of infections [33].

\section{Pregnant animals and human}

Maternally listeriosis increases during pregnancy, particularly in the third trimester. Most infected pregnant ruminates and women have mild illness unless they have another underlying illness. In Pregnant women naturally have a depressed cell-mediated immune system [24].

However, about $20 \%$ of cases result in spontaneous abortion or neonatal death, and surviving infants develop sepsis or meningitis [33].

Table 1: Prevalence study conducted on Listeria in animals and humans in Ethiopia.

\begin{tabular}{|c|c|c|c|c|}
\hline Study area & Sample type & No of sample & Prevalence (\%) & Authors \\
\hline Haramaya University Dairy farm & Silage and water, Cow barn, Milk cow, Milking operation, Milk auditing, Milk supply & 200 & $20 \%$ & [28] \\
\hline Debre-Birhan Town & Bovine raw milk & 407 & $20.88 \%$ & [37] \\
\hline Bishoftu and Dukem & Food of animal origin & 340 & $32.9 \%$ & [38] \\
\hline Arsi and West shew & Food of animal origin & 247 & $42.9 \%$ & [8] \\
\hline Central highlands of Ethiopia. & Raw milk and milk Products & 443 & 28.4 & [39] \\
\hline Gondar Town & Foods of animal Origin & 384 & 25 & [5] \\
\hline North Shewa & Raw milk and dairy Products & 384 & 24.2 & [40] \\
\hline Addis Ababa & Sheep meat from abattoir and butcher shops & 384 & 3.8 & [9] \\
\hline Jimma Town & Retail meat and dairy product & 390 & 14 & [41] \\
\hline Addis Ababa & Food of animal origin & 240 & 27.5 & [42] \\
\hline Addis Ababa & Foods of animal origin and raw meat products & 384 & $26.6 \%$ & [43] \\
\hline Addis Ababa & Food of animal origin & 391 & $26.1 \%$ & [44] \\
\hline Addis Ababa, & Retail meat and milk products & 384 & $32.6 \%$ & [10] \\
\hline & & & & 156 \\
\hline
\end{tabular}




\section{Immunocompromised individuals}

Individuals having weakened cell-mediated immunity are more susceptible for infection of the disease. During medical conditions and medications that decrease $\mathrm{T}$-cell mediated immunity increase the risk of listeriosis. Transplants and blood-related cancers confer the greatest risk. HIV seems to rarely lead to listeriosis since the advent of Highly Active AntiRetroviral Therapy and Trimethoprim-Sulfamethoxazole. Disease like: cancers, liver disease and diabetes all confer a moderate risk of infection [34].

\section{Public healthy importance}

Listerosis is not only an intracellular pathogenic bacterium for animals that but it has become an important cause of human food borne infections worldwide. Among listeria species L. monocytogenes is an infective to all human population group it has a propensity to cause especially severe problems in pregnant women, neonates, the elderly and immunosuppressed individuals [35].

Direct transmission from animals to human is possible especially among veterinarians performing gynecological interventions with aborted animals. Animals may be diseased or asymptomatic carriers of L. Monocytogenes shedding the organism in their feces. In Ethiopia the most problem of the disease due to indirect transmission occur simply by consumption of food products from diseased animals [8] reported that on-farm manufactured raw milk cheese made from cattle. Raw or contaminated milk, vegetables and readyto-eat meat have been implicated in overseas outbreaks [5].

Contamination could be during preparation and it then multiplies during the storage process. Unlike some other food borne pathogens, Listeria monocytogenes can multiply in contaminated refrigerated food For example, soft cheese is considered as a high risk product for listeriosis because the bacteria may grow to significant numbers during refrigeration [10].

\section{Conclusions and recommendations}

Listeria has gained recognition global as human and animal pathogen. It can grow in a wide range of temperature. In Ethiopia listeria were reported from Retail meat and milk products, from Silage and water, Cow barn, Milk cow, Milking operation, Milk auditing, Milk supply, and raw meat products, from raw bovine milk. So far the prevalence of the disease ranges from 3.8\% from sheep meat from abattoir and butcher shops and $42.9 \%$ from milk and milk products in the country. Maintaining hygiene for preservation of silage and processing machines are the keys in preventing for epidemiology of Listeria species. It should be properly reheated before consumption by immune compromised, pregnant animals and human in order to eliminate possible contamination.

\section{Based above information the following recommenda- tions are forwarded}

\section{Afood safety management system based on the principles}

of HACCP with regular reviews should be developed and implemented in dairy and food processing industries.

$>$ There should be treated meat and milk products with heat before consumption which can kill Listeria species

There should be carried out health education for community about the disease.

\section{References}

1. Kalorey D, Warke S, Kurkure N, Rawoo D, Barbuddhe S (2008) Listeria species in bovine raw milk: A large survey of central India. Journal Food Control 19 109-112. Link: https://bit.ly/2luov8A

2. Painter J, Slutsker L (2007) Listeriosis in human and Food Safety. $3^{\text {th }}$. Ed Ryser, Tand, Marth. CRC Press, Taylor \& Francis Group Boca Raton, Florida, USA 85-110.

3. Mola B, Yilma R, Alemayehu D (2004) Listeria monocytogenes and other Listeria Species in retail meat and milk products in Addis .Ababa, Ethiopia: Ethio J Health Dev 18: 131-212. Link: https://bit.ly/3ljuN9s

4. Tsehay R (2002) Small-scale milk marketing and processing in Ethiopia In: Rangnekar D, Thorpe W, eds. Smallholder dairy production and marketing opportunities and constraints. Nairobi, Kenya: International Livestock Research Institute. Link: https://bit.ly/32T8u3t

5. Garedew L, Taddese A, Biru T, Nigatu S, Kebede E (2015) Prevalence and Antimicrobial susceptibility profile of listeria species from ready-to-eat foods of animal origin in Gondar Town, Ethiopia. BMC Microbiol 15: 1-6. Link: https://bit.ly/3esss4M

6. Central Statistics Agency (2001) Report on the 1999/2000 household and expenditure survey.Addis Ababa, Ethiopia.

7. Tewodros F, Atsedewoyne F (2012) Listeriosis in Small Ruminants: Advance in Biological Research 6: 202-209.

8. Hiwot D, Savoinni G, Cattaneo D, Gabriella S, Martino P (2016) Bacteriological Quality of Milk in Raw Bovine Bulk Milk in the Selected Milk Collection Centers: Smallholder Dairy Processing Ethiopia. Link: https://bit.ly/2IrU080

9. Selamawit M (2014) The Prevalence, Risk Factors Public Health Implication And Antibiogram Of Listeria Monocytogenes In Sheep Meat Collected From Municipal Abattoir And Butcher Shops In Addis Ababa.

10. Ooi L, Lorber B (2005) Gastroenteritis due to Listeria monocytogenes, Clinica Infectious Diseases 40: 1327-1332. Link: https://bit.ly/35kYaCG

11. Hitchins A (2002) Detection and enumeration of Listeria monocytogenes in foods. In:Bacteriological Analytical Manual online. $8^{\text {th }} \mathrm{Ed}$

12. Radostits O, Gay C, Hincheliff K, Constable P (2007) Diseases associated with Listeria species: Veterinary Medicine, a Textbook of the disease of Cattle, Sheep, Pigs, Goats and Horses. 10 Ed. Saunders Elsevier Published Ltd, London 805-810.

13. Pal M, Awel H (2013) Public Health Significance of Listeria monocytogenes in Milk and Milk Products: An Overview, Department of Microbiology, Immunology and Public Health, College of Veterinary Medicine and Agriculture, Addis Ababa University, P.O. Box No, 34, Debre Zeit, Ethiopia. Link: https://bit.ly/2UgidvX

14. Aureli P, Fiorucci GC, Caroli D, Marchiaro G, Novara O, et al. (2001) An outbreak of febrile gastroenteritis associated with corn contaminated by Listeria monocytogenes. N Eng Journal Med 342: 1236-2000. Link: https://bit.ly/3lpHMGP

15. Todar's online textbook of bacteriology (2003) Listeria monocytogen and listeriosis.kenneth Todar University of Wisconsin-madison Department of Bacteriology. 
16. Dieterich G, Karst U, Fischer E, Wehland J, Jansch L (2006) Knowledge database and visualization tool for comparative genomics of pathogenic and non-pathogenic Listeria species. Nucleic Acids Res 34: 402-406. Link: https://bit.ly/35n78zq

17. Bibek R, Arun B (2008) Fundamental Food Microbiology. CRC Press, United States, 4th ed, USA 288-294.

18. Lorber B (2005) Listeria monocytogenes. In: Mandell GL, Bennett JE, Dolin R: Mandell, Douglas, and Bennett's Principles and Practice of Infectious Diseases. 6 Ed. Elsevier Churchill Livingstone, Philadelphia. 2478-2484.

19. Wiedmann M, Jeffers J, Bruce $P$, McDonough J, Boor K (2001) Comparativegenetic characterization of Listeria monocytogenes isolates from human and animal listeriosis cases. Microbiology 147: 1095-1104. Link: https://bit.ly/2Uhr407

20. Hough A, Harbison M, Savill L, Melton G (2002) Rapid enumeration of Listeria monocytogenes in artificially contaminated cabbage using real-time polymerase chain reaction. J Food Prot 65: 1329-1332. Link: https://bit.ly/35kxvpJ

21. Staric J, Krianec F, Zadnik T (2008) Listeria monocytogenes keratoconjunctivitis in dairy cattle. University of Ljubljana, Veterinary Faculty, Clinic for Ruminants,1000 Ljubljana, Slovenia ivinozdravniš kaambulanta Kri and Za, 2326Cirkovce, Slovenia.Veterinary Record, 158: 588-592. Link: https://bit.ly/2GYlj3y

22. Richard L, Laurie C, Judy D (2008) The Food Safety Hazard Guide Book. Food Safetylnformation, London, UK 47-49. Link: https://rsc.li/35pBTnv

23. Clark R, Gill J, Swanney S (2004) Listeria monocytogenes gastroenteritis in sheep. New Zealand Veterinary Journal 52: 46-47. Link: https://bit.ly/3pk8KC3

24. Cherubin C, Appleman M, Heseltine P (1991) Epidemiological Spectrum and Current Treatment of Listeriosis. Clinical Infectious Diseases 13: 1108-1114. Link: https://bit.ly/32ykVkH

25. Heikkinen T, Laine P, Neuvonen K, Ebald U (2000) The transplacental transfer of themacrolideantibiotics erythromycin, roxithromycin and azithromycin. International Journal of Ostetrics and Gyenaecology 107: 770-775. Link: https://bit.ly/3eP5auT

26. Hussein M (2018) Detection of Possible Sources of Listeria monocytogenes and other Listeria Species and their Antimicrobial Resistance Profiles along Haramaya University Dairy Farm Operational stages, Oromia Regional State, M.Sc. Thesis, Haroomaya University College of veterinary medicine, haromaya, Ethiopia.

27. Quinn P,Markey J,Donnelly W,Carter A, LeonardF(2002)VeterinaryMicrobiology and Microbial Disease. Published Blackwell publishing; UK (Great Britain) 162 165

28. Pal M (2007) Zoonoses. $2^{\text {nd }}$. Satyam Publishers, Jaipur, India 118-119. Link: https://bit.ly/3nf1Gon

29. Heymann D (2004) Control of communicable diseases manual. $18^{\text {th }}$ ed Washington: American Public Health Association.

30. Perianu Y, Bolile D (2004) Infecpious Animal or Domestic. Vol. I,Bacterioze, Ed.Venus, lai 431-443.

31. Hirsh C, Maclachlan J, Walklers L (2004) Veterinary Microbiology. $2^{\text {th }}$ ed, Blackwell publishing, USA, 185-189. Link: https://bit.ly/36vnYeD

32. Galanis E, David P (2008) Risk of Listeriosis Associated with Age, Pregnancy and Various Conditions. Prepared by BCCDC for the BC Food Safety in Facilities Advisory Group.
33. Cossart P (2004) The infection by Listeria monocytogenes towards acompleteunderstanding of human listeriosis. XV International Symposium on Problems of Listeriosis 131.

34. Liu D (2006) Identification, subtyping and virulence determination L. monocytogenes: An important food borne pathogen. J Med Microbiol 55: 645659. Link: https://bit.ly/2K1RVvx

35. Yeshibelay G, Abebe B (2018) Isolation, identification and antimicrobial susceptibility of Listeria species from raw bovine milk in Debre-Birhan, Ethiopia. Journal of Zoonotic and Public Health 2: 4. Link: https://bit.ly/2GReG3U

36. Sintayehu F (2017) Occurrence of Listeria monocytogenes in Ready to Eat Foods of Animal origin and its Antibiotic susceptibility profile, Bishoftu and Dukem towns, Centeral Ethiopia. World Journal of Advance Healthcare Research 1: 47-62. Link: https://bit.ly/35nhwqZ

37. Eyasu T, Daniel A, Tesfu K, Haile A, Wondwossen A (2015) Prevalence of Listeria monocytogenes in raw bovine milk and milk products from central highlands of Ethiopia. J Infect Dev Ctries 9:1204-1209. Link: https://bit.ly/2JRY3pU

38. Tefera H (2014) Prevalence and antibiotic susceptibility of Listeria species in raw milk anddairy products from North Shewa Zone, Oromia Regional state. DVM thesis Haramaya University, Ethiopia.

39. Muhammed W, Muleta D, Deneke Y, Ashaw A, et al. (2013) Studies on occurence of listeria monocytogenes and other species in milk and milk products in retail market of jimma town. Jimma University, College of Agriculture and Veterinary Jimma, Ethiopia. Link: https://bit.ly/38uYIYO

40. Firehiwot A, Karlsmose S, Monga D, Mache A, Svendsen C, Felix B, et al. (2013) Occurrence of Listeria speices. In retail meat and dairy products in the area of Addis Ababa, Ethiopia. Foodborne Pathog Dis 10: 577-579. Link: https://bit.ly/38xmPpK

41. Mengesha D, Ewde M, Toquin J, Kleer G, Hildebrandt W, et al. (2009) Occurrence and distribution of Listeria monocytogenes and other Listeria species in readyto-eat and raw meat products. Berl Munch Tierarztl Wochenschr 122: 20-24. Link: https://bit.ly/35sbaGz

42. Nigatu K, Gebretsadik S, Tesfu K, Haile A, Kahsay H (2010) Isolation and characterization of Listeria monocytogenes and other Listeria species in foods of animal origin in Addis Ababa, Ethiopia.

\section{Discover a bigger Impact and Visibility of your article publication with}

\section{Peertechz Publications}

\section{Highlights}

* Signatory publisher of ORCID

* Signatory Publisher of DORA (San Francisco Declaration on Research Assessment)

* Articles archived in worlds' renowned service providers such as Portico, CNKI, AGRIS, TDNet, Base (Bielefeld University Library), CrossRef, Scilit, J-Gate etc.

* Journals indexed in ICMJE, SHERPA/ROMEO, Google Scholar etc.

* OAl-PMH (Open Archives Initiative Protocol for Metadata Harvesting)

* Dedicated Editorial Board for every journal

* Accurate and rapid peer-review process

* Increased citations of published articles through promotions

* Reduced timeline for article publication

Submit your articles and experience a new surge in publication services (https://www.peertechz.com/submission).

Peertechz journals wishes everlasting success in your every endeavours.

Copyright: () 2020 Bayata SD. This is an open-access article distributed under the terms of the Creative Commons Attribution License, which permits unrestricted use, distribution, and reproduction in any medium, provided the original author and source are credited. 